Diskursus: Jurnal Pendidikan Bahasa Indonesia

Vol. 3, No. 3, Desember 2020, pp. 226-239

p-ISSN: $2615-4935$

e-ISSN: 2615-4943

\title{
Nilai Religius dan Nilai Budaya dalam Novel Dendam si Yatim-Piatu Karya Sintha Rosse
}

\author{
Irawan Suharja \\ Universitas Indraprasta PGRI \\ Jalan Nangka No. 58 C/TB. Simatupang, Tanjung Barat, Jakarta Selatan 12530 \\ E. Zaenal Arifin \\ Universitas Indraprasta PGRI \\ Jalan Nangka No. 58 C/TB. Simatupang, Tanjung Barat, Jakarta Selatan 12530 \\ Masrin \\ Universitas Indraprasta PGRI \\ Jalan Nangka No. 58 C/TB. Simatupang, Tanjung Barat, Jakarta Selatan 12530 \\ Irawanherba89@gmail.com ${ }^{1)}$
}

\begin{abstract}
Revenge of the Orphans by Sintha Rosse is the creativity of the writer who describes the struggle of the main character's life. This study aims to describe the religious values and cultural values in this novel. This research is a qualitative research using Michael Riffaterre's semiotic approach which is used for heuristic and hermeneutic readings on the research object. This research determines the religious value in this novel in the form of (1) creed, (2) sharia, (3) morals. Religious life elevates the main orphaned characters, who live nomadic, hitchhike from one person to another, have nothing and don't think of being anything, but in the storytellers are able to achieve their ideals and blessings thanks to prayer and outside effort. as well as support from the family. The cultural values determined in this novel are cultural manifestations, (1) an idea, ideas, values, regulatory norms and so on, (2) a patterned behavior activity from humans in a community, (3) objects human workmanship. The main character who is diligent, smart and never gives up, becomes a positive value for his readers.
\end{abstract}

Keywords: Religious Values, Cultural Values and Novels.

\begin{abstract}
Abstrak
Dendam si Yatim-Piatu karya Sintha Rosse merupakan kreativitas penulis yang mendeskripsikan perjuangan hidup tokoh utama. Penelitian ini bertujuan untuk mendeskripsikan nilai religius dan nilai budaya dalam novel ini. Penelitian ini adalah penelitian kualitatif dengan pendekatan semiotik Michael Riffaterre yang digunakan untuk pembacaan heuristik dan hermeneutik pada objek penelitian. Penelitian ini menentukan nilai religius di dalam novel ini berupa (1) akidah, (2) syariah, (3) akhlak. Kehidupan religius mengangkat tokoh utama yang yatim-piatu, yang hidup nomaden, menumpang dari satu orang ke orang lain, tidak punya apa-apa dan tidak berpikir menjadi apa-apa, namun di penunjung cerita mampu meraih cita dan asanya berkat doa dan usaha yang luar biasa serta dukungan dari keluarga. Nilai budaya yang ditentukan dalam novel ini adalah wujud budaya, (1) suatu ide, gagasan, nilai-nilai, norma-norma peraturan dan sebagainya, (2) suatu aktifitas kelakuan berpola dari manusia dalam sebuah komunitas masyarakat, (3) benda-benda hasil karya manusia. Tokoh utama yang rajin, pandai dan pantang menyerah, menjadi nilai postif bagi para pembacanya.
\end{abstract}

Kata Kunci: Nilai Religius, Nilai Budaya dan Novel. 


\section{PENDAHULUAN}

Fenomena kehidupan masyarakat dilihat dari aspek agama dan budaya yang bagaimana menempatkan posisi agama dan posisi budaya dalam suatu kehidupan masyarakat. Dalam kehidupan manusia, agama dan budaya jelas tidak berdiri sendiri, keduanya memiliki hubungan yang sangat erat dalam dialektikanya, selaras menciptakan dan kemudian saling menegasikan.

Agama sebagai pedoman hidup manusia yang diciptakan oleh Tuhan, dalam menjalani kehidupannya. Sedangkan budaya adalah sebagai kebiasaan tata cara hidup manusia yang diciptakan oleh manusia itu sendiri dari hasil daya cipta, rasa dan karsanya yang diberikan oleh Tuhan.

Agama dan budaya saling mempengaruhi satu sama lain. Agama mempengaruhi kebudayaan, kelompok masyarakat, dan suku bangsa. Budaya cenderung berubah-ubah yang berimplikasi pada keaslian agama sehingga menghasilkan penafsiran berlainan. Salah satu agenda besar dalam kehidupan masyarakat, berbangsa dan bernegara adalah menjaga persatuan dan kesatuan dan membangun kesejahteraan hidup bersama seluruh warga negara dan umat beragama.

Penulis masih sering menyaksikan adanya sebahagian anggota masyarakat yang mencampur adukkan antara nilai-nilai agama dengan nilai-nilai budaya yang padahal kedua hal tersebut tentu saja tidak dapat seratus persen disamakan, bahkan mungkin berlawanan. Demi terjaganya esistensi dan kesucian nilai-nilai agama sekaligus memberi pengertian, disini penulis hendak mengulas mengenai nilai agama dan nilai budaya yang memiliki hubungan yang kuat.

Karya sastra merupakan hasil pemikiran, perasaan, dan keinginan pengarang melalui bahasa. Karya sastra terdiri dari beragam bentuk, yaitu puisi, prosa, dan drama. Prosa dapat berupa novel, roman, dan cerpen. Dengan hadirnya karya sastra yang membicarakan persoalan tentang manusia, antara karya dan manusia tidak dapat dipisahkan satu sama lain. Karya sastra dengan segala ekspresinya merupakan pencerminan kehidupan masyarakat.

Karya sastra yang menggambarkan kehidupan bermasyarakat tercermin dalam novel. Novel merupakan objek manusiawi, fakta kemanusiaan, dan fakta kultural karena berupa hasil ciptaan manusia yang luas dan kompleks. Sebagai objek manusiawi, novel diciptakan sebagai wadah yang dapat memberikan kontribusi bagi masyarakat baik sebagai alat membentuk karakter maupun sebagai alat untuk menghibur.

Sebagai fakta kemanusiaan, novel dibuat berdasarkan gambaran dan cerminan kehidupan manusia. Sebagai fakta kultural, novel dibuat berdasarkan fakta kemanusiaan yang tidak terlepas dari kebudayaan. Berdasarkan hal tersebut, novel dianggap sebagai hasil dialog-perenungan pengarang terhadap kehidupan, mengangkat dan mengungkapkan kembali berbagai permasalahan hidup dan kehidupan setelah melewati penghayatan yang intens, seleksi-subjektif, dan diolah dengan daya imajinatif kreatif oleh pengarang ke dalam bentuk dunia rekaan sesuai dengan keyakinan dan idealismenya.

Pengarang menciptakan novel dalam hidup dan kehidupan melalui kegiatan pengimitasian sebagai hasil interpretasi. Selain itu, juga dibangun atas hubungan antara tanda dan makna, antara ekspresi dengan pikiran, antara aspek luar 
dengan aspek dalam. Bahasa yang digunakan pengarang bersifat ekspresif, konotasi, estetis, dan lebih mementingkan simbol atau bahasa yang memuat tandatanda.

Karya sastra sebagai fakta semiotik bukan sekadar melihat arti bahasa melainkan juga menginterpretasikan makna dalam hal penggunaan tanda (sign), lambang (symbol), dan isyarat (signal). Pemahaman mengenai lambang mencakup pemahaman masalah penanda (signifier; signans; signifant) dan petanda (signified; signatum; signifie). Dengan adanya penjelasan tersebut, tanda yang akan menjadi kajian dalam penelitian ini dibedakakan dua yaitu, tanda verbal dan tanda nonverbal.

Berdasarkan hal tersebut, bisa dikatakan bahwa semiotika merupakan ilmu tanda yang meliputi segenap aspek kehidupan manusia yang dipandang sebagai tanda, seperti kata, gerak syarat, lampu lalu lintas, bendera, nyanyian, gerak-gerik, dan sebagainya yang mewakili sesuatu yang lain.

Dendam si Yatim Piatu merupakan novel karya Sintha Rose. Novel ini bertemakan kehidupan seorang anak lelaki yang menjadi yatim piatu sejak berumur 5 tahun. Novel Dendam si Yatim Piatu menceritakan kisah kehidupan Malik Ibnu Sabil dari kecil. Malik kecil lahir dan besar dari pasangan suami istri yang saling mencintai. Sehingga ruang batin Malik selalu terisi dengan kebahagiaan.

Dengan hadirnya novel "Dendam" Si Yatim-Piatu karya Sintha Rosse sebagai bahan bacaan yang cukup mendapat perhatian, khususnya bagi mereka yang gemar membaca fiksi. Penulis berharap novel ini dapat dijadikan cermin atau bahan pertimbangan dan pemikiran bagi generasi muda dengan memaparkan nilainilai religius dan budaya yang terkandung di dalam novel tersebut.

Novel ini juga memberikan inspirasi dan contoh bagi generasi muda yang akhir-akhir ini mudah terjerambab dengan pergaulan bebas, minim cita-cita, dan bekal agama. Novel ini mengajak anak muda dan keluarga berubah ke arah yang lebih baik. Oleh karena kondisi di atas, penulis berkeinginan untuk menganalisis novel ini.

\section{METODE}

Penelitian ini menggunakan pendekatan kualitatif dengan metode semiotik. Menurut Bogdan (dalam Ahmadi, 2016:15) pendekatan kualitatif adalah prosedur penelitian yang menghasilkan data naturalistik terhadap pokok persoalannya. Moelong (2002:6) mengemukakan bahwa metode penelitian kualitatif merupakan prosedur penelitian yang menghasilkan data deskriptif berupa kata-kata tertulis atu lisan tentang sifat suatu individu, keadaan, atau gejala dari kelompok tertentu yang diamati.

Metode semiotik itu sendiri merupakan ilmu tentang tanda-tanda, ilmu yang menganggap bahwa fenomena sosial/ masyarakat dan kebudayaan itu merupakan tanda-tanda. Selain itu juga mempelajari sistem-sistem, aturan-aturan, dan konvensi-konvensi yang memungkinkan tanda-tanda tersebut mempunyai arti (Pradopo, 2008: 119). Penelitian dengan metode semiotik ini bertujuan untuk mengetahui arti yang terdapat dalam tanda-tanda pada objek penelitian. Fokus 
penelitian ini terdapat pada penelitian makna heuristik dan hermeneutik novel "Dendam si Yatim-Piatu".

Analisis ini dilakukan dengan teori semiotik Michael Riffaterre yang digunakan untuk pembacaan heuristik dan hermeneutik pada objek penelitian. Metode pembacaan heuristik merupakan cara kerja yang dilakukan oleh pembaca dengan menginterpretasikan secara stuktural. Artinya, pada tahap ini pembaca dapat menemukan arti (meaning) secara linguistik. Adapun metode pembacaan hermeneutik untuk mencari makna (meaning of meaning atau significance). Metode ini merupakan cara kerja yang dilakukan oleh pembaca dengan bekerja secara bolak-balik dari awal sampai akhir. Dengan pembacaan bolak-balik itu, pembaca dapat mengingat peristiwa-peristiwa atau kejadian-kejadian di dalam teks sastra yang baru dibaca. Selanjutnya, pembaca menghubungkan kejadian-kejadian tersebut antara yang satu dengan yang lainnya. Sampai ia dapat menemukan makna karya sastra pada sistem sastra yang tertinggi, yaitu makna keseluruhan teks sebagai sistem tanda (Riffaterre dalam Sangidu, 2004: 19).

Sumber data pada penelitian ini adalah dialog. Menurut Rani (dalam Hilaliyah dan Awaludin, 2016: 75), "Dialog merupakan komunikasi yang terjadi antara dua orang yang bergantian peran (dari pembicara menjadi pendengar atau sebaliknya)." Teknik pengumpulan data merupakan langkah yang paling utama dalam penelitian, karena tujuan utama dari penelitian adalah mendapatkan data (Sugiyono, 2012:308). Teknik pengumpulan data yang digunakan penulis dalam penelitian ini adalah teknik pustaka, teknik baca, dan teknik catat. Teknik pustaka adalah studi kepustakaan yang berkaitan dengan kajian teoretis dan referensi lain yang terkait dengan nilai, budaya, dan norma yang berkembang pada situasi yang diteliti (Sugiyono, 2010:398).

Teknik baca adalah teknik pengumpulan data yang dilakukan dengan bekerja secara terus menerus lewat pembacaan teks sastra secara bolak-balik dari awal sampai akhir (Sangidu, 2004:19). Teknik catat adalah teknik mengumpulkan data yang melakukan pencatatan pada kartu data yang dilanjutkan klasifikasi setelah teknik pertama atau kedua selesai digunakan-diterapkan atau sesudah perekaman dilakukan, dan dengan menggunakan alat tulis tertentu (Sudaryanto, 2015:205206).

\section{HASIL DAN PEMBAHASAN}

\section{Hasil}

Tabel 1. Hasil Temuan Nilai Religius

\begin{tabular}{ccccc}
\hline Indikator & \multicolumn{3}{c}{ Nilai Religius } & Jumlah \\
\cline { 2 - 4 } & I & II & III & \\
Jumlah & 35 & 47 & 46 & 128 \\
Persentase & $27,34 \%$ & $36,71 \%$ & $35,93 \%$ & $100 \%$ \\
\hline
\end{tabular}


Tabel 2. Hasil Temuan Nilai Budaya

\begin{tabular}{ccccc}
\hline Indikator & \multicolumn{3}{c}{ Nilai Budaya } & Jumlah \\
\cline { 2 - 4 } & I & II & III & \\
Jumlah & 42 & 30 & 37 & 109 \\
Persentase & $38,53 \%$ & $27,52 \%$ & $33,94 \%$ & $100 \%$ \\
\hline
\end{tabular}

\section{Pembahasan}

\section{Nilai Religius}

Nilai religius memiliki tiga unsur pokok yaitu aqidah, ibadah, dan akhlak yang menjadi pedoman perilaku sesuai dengan aturan-aturan illahi untuk mencapai kesejahteraan serta kebahagian hidup di dunia dan akhirat. Bila nilai-nilai religius tersebut telah tertanam pada diri seseorang dan dipupuk dengan baik, maka dengan sendirinya akan tumbuh dengan jiwa agama (Sahlan, 2010:69).

\section{Penafsiran Temuan Penelitian tentang Akidah}

Munawwir (dalam Marzuki, 2012: 86) mengatakan bahwa akidah berasal dari kata 'aqada-ya'qidu-'aqdlan yang berarti 'menyimpulkan', 'meningkatkan', 'mengokohkan', dan 'mengadakan perjanjian'. Setelah terbentuk menjadi 'aqidatan ('aqidah) berarti 'kepercayaan' atau 'keyakinan'.

Jika dikembalikan kepada sumber pokok ajaran islam (termasuk akidah), yaitu Alquran dan Assunnah, maka pokok-pokok keimanan dalam islam dirumuskan menjadi enam, inilah yang kemudian dikenal dengan "rukun iman yang enam". Keenam rukun iman yang dimaksud, yaitu :

1. Iman kepada Allah

2. Iman kepada Malaikat

3. Iman kepada kitab-kitab

4. Iman kepada Rasul-Rasul

5. Iman kepada Hari Akhir

6. Iman kepada qadla' dan qadar Allah ( Marzuki, 2012:88).

Novel "Dendam" si Yatim-Piatu mendeskripsikan nilai religius yang berupa Akidah seperti yang terdapat pada kalimat berikut :

Iman kepada Allah

Dalam Kamus Besar Bahasa Indonesia iman ialah kepercayaan yang berkenaan dengan agama atau juga keyakinan dan kepercyaan kepada Allah, Nabi, dan Kitab.

Keyakinan kepada Allah Yang Maha Esa (tauhid) merupakan titik sentral keimanan. Setiap aktivitas seorang muslim harus senantiasa vertikal kepada Allah SWT. Pekerjaan seorang muslim yang dilandasi keimanan dan dimulai dengan niat karena Allah akan mempunyai nilai ibadah disisi Allah ( Marzuki, 2012:88).

Malik digambarkan seorang anak yang percaya pada Tuhan. Seperti pada kutipan novel "Dendam" si Yatim-Piatu yang berupa tentang Iman kepada Allah. 
"Iya, Malik harus percaya bahwa Tuhan itu Maha Baik, Maha Pengasih, Maha Penyayang, dan selalu memberikan yang terbaik buat hamba-Nya. Tuhan tidka akan memberikan cobaan di luar batas kemampuan manusia, dan semua yang terjadi atas kehendak-Nya.”(Rosse, 2019:26)

1. Iman kepada Malaikat

Iman kepada Malaikat adalah keyakinan bahwa Allah menciptakan sekelompok makhluk (Malaikat) yang selalu taat kepada-Nya dan tidak diberi kemampuan untuk mengingkarinya. Mereka adalah makhluk yang bertugas melaksanakan semua perintah Allah SWT ( Marzuki, 2012:92).

Kutipan iman kepada malaikat dalam novel "Dendam" si Yatim-Piatu menggambarkan bahwa Malik meyakini keberadaan Malaikat, sebagai berikut:

Malik teringat sebuah sabda Rasulullah Shalallahu'Alaihi Wassalam, yang menjadikan bunyi kokok ayam jantan di waktu malam sebagai pertanda kebaikan, yakni datangnya malaikat (Rosse:108).

2. Iman kepada Kitab

Iman kepada kitab suci merupakan konsekuensi logis dari iman kepada Allah karena hanya kepada orang-orang yang dipilih-Nya. Secara khusus seorang muslim harus meyakini kitab-kitab yang nama-namanya telah diberitakan Allah kepada manusia ( Marzuki, 2012:95).

Dari pengertian di atas penulis menyimpulkan bahwa iman kepada kitab ialah mempercayai bahwa Allah telah mewahyukan kitab/Alquran kepada nabi Muhammad yang telah dipilihn-Nya dan Alquran merupakan firman Allah yang harus dijadikan pedoman dalam kehidupan sehari-hari.

Iman kepada kitab pada novel "Dendam" si Yatim-Piatu, Malik meyakini isi dalam Kitab Al-Qur'an dalam surat al-Baqorah : 117

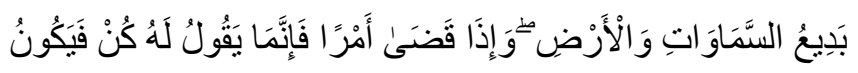

Artinya: Allah Pencipta langit dan bumi, dan bila Dia berkehendak (untuk menciptakan) sesuatu, maka (cukuplah) Dia hanya mengatakan kepadanya: "Jadilah!" Lalu jadilah ia.

Pada kutipan berikut:

Betapa Tuhan Maha Berkehendak, Kun Faya Kun, jadilah makan terjadilah ia.(Rosse, 2019:244).

3. Iman kepada Rasul

Secara umum setiap muslim wajib beriman bahwa Allah telah mengutus kepada manusia beberapa orang Rasul (Nabi) dari kalangan manusia sendiri yang bertugas membimbing manusia ke arah jalan yang lebih benar. Rasul atau nabi yang disebutkan dalam Alquran lebih kurang 25 Rasul/Nabi yang juga harus diimani oleh setiap orang islam ( Marzuki, 2012:98). 
Kutipan yang berupa iman kepada Rasul dalam novel "Dendam" si Yatim-Piatu, Malik mengimani Hadist nabi Muhammad Saw dan percaya akan kebenaran ajaran Baliau, sebagai berikut :

Malik teringat sebuah sabda Rasulullah Shalallahu'Alaihi Wassalam, yang menjadikan bunyi kokok ayam jantan di waktu malam sebagai pertanda kebaikan, yakni datangnya malaikat.(Rosse, 2019:108).

4. Iman kepada Qadla dan Qadar

Dalam Kamus Besar Bahasa Indonesia qada ialah peraturan, hukum, ketentuan yang berasal dari Allah. Qadla' menurut bahasa berarti 'hukum', 'perintah', 'memberikan', 'menghendaki', dan 'menjadikan'. Sedang qadar berarti 'batasan', 'menetapkan ukuran'. Secara sederhana dapat diartikan bahwa qadla' adalah 'ketetapan Allah yang telah ditetapkan (tetapi tidak diketahui)', sedang qadar adalah 'ketetapan Allah yang telah terbukti (diketahui sudah terjadi)' ( Marzuki, 2012:100).

Dari pengertian di atas penulis menyimpulkan bahwa iman kepada qada dan qadar yaitu percaya terhadap segala takdir yang Allah tetapkan baik yang belum terjadi atau yang sudah terjadi. Kutipan berupa iman kepada qadla dan qadar pada novel "Dendam" si Yatim-Piatu, sebagai berikut :

Wafatnya ayah Malik yang merupakan ketentuan dari Yang MahaKuasa, Malik meyakini ayahnya dipanggil oleh Tuhan yang mengatur takdir hamba-Nya.

"Malik, Abi kamu meninggal dunia, telah dipanggil oleh yang

Mahakuasa, berpulang ke Rahmatullah.'(Rosse, 2019:27)

Keyakinan Aisyah qodar itu ujian dari Tuhan bagi setiap hamba-Nya, dan semua tentang kehidupan telah ditakdirkan dan dicatat dalam kitab Lauhful Mahfuzh:

Sabar, Aisyah. Nasib malang itu ujian dari Allah.(Rosse, 2019:40)

Padahal, semua yang terjadi di muka bumi, telah tercatat dalam kitab Lauh Mahfuzh.(Rosse, 2019:60)

\section{Penafsiran Temuan Nilai Religius Syariah}

Berdasarkan pendapat di atas maka yang dimaksud dalam syariat yaitu ibadah. Ibadah diartikan 'segala sesuatu yang dikerjakan untuk mencapai keridaan Allah dan mengharap pahala-Nya di akhirat.

Kutipan novel "Dendam" si Yatim-Piatu mendeskripsikan nilai religius berupa syariah yaitu mengerjakan sholat wajib dan beramal kepada Allah Swt dengan ikhlas, seperti yang terdapat pada kalimat berikut :

"Pak Ramis, Pak Ramis, saya izin mau sholat Subuh di mushola dulu."(Rosse, 2019:73)

"Tapi ingat, mengajar ini karena Allah. Kita tidak boleh mengaharapkan imbalan dari anak-anak yang kita ajarkan.”(Rosse, 2019:87)

\section{Penafsiran Temuan Penelitian tentang Akhlak}

Dalam Kamus Besar Bahasa Indonesia akhlak yaitu berarti budi pekerti; kelakuan. Secara etimologi, akhlak berasal dari bahasa Arab khalaqa, khuluqun 
yang berarti tabiat atau perangai. Dalam pengertian ini, maka akhlak dapat bersifat positif maupun negatif, bergantung pada tatanan nilai yang menjadi landasannya.

Menurut Kahar Mansyur, akhlak terbagi menjadi dua macam, yaitu

1. Akhlak baik (akhlaqul Mahmuudah)

2. Akhlak buruk (akhlaqul madzmuumah)

\title{
Akhlak baik
}

Akhlak baik adalah akhlak yang sesuai dengan ajaran Allah SWT, yaitu beriman kepada Allah, rajin beribadah, membayar zakat, memelihara aurat, menepati janji, suka damai, mengajak kepada makruf, mencegah perbuatan mungkar, menjaga batas aturan Allah SWT, rendah hati, hidup sederhana, memelihara kemaluan, jadi saksi yang jujur, tidak berzina, tidak berbuat sombong, suka berkata yang baik, tidak boros, tidak kikir, memuliakan tamu, memuliakan tetangga, menjawab pertanyaan orang dengan baik, dan suka berkata yang baik.

Kutipan Pada Novel "Dendam" si Yatim-Piatu mendeskripsikan nilai religius berupa akhlak baik digambarkan pada sosok Kiai Mahfud yang rela berkorban, seperti yang terdapat pada kutipan berikut:

Kiai Mahfud sosok yang sangat disegani orang. Meskinpun berperangai keras dan tegas, tapi ia dikenal sebagai pemimpin yang rela mengorbankan segenap jiwa dan raga untuk kepentingan pesantren. Ia juga mengemban amanat memimpin Nahdlatul Ulama kota Tasikmalaya.(Rosse, 2019:7)

Nilai religius akhlak baik berupa permohonan maaf dari Pak Dadang, yang telah mengakui kesalahannya kepada kiai Mahfud :

"Maaf, Kiai Mahfud, saya khilaf," ucapnya sestelah membalut luka Malik dengan perban.(Rosse, 2019:11)

Nilai religius ahlak baik berupa mengajak pada berbuatan makruf oleh Kiai Mahfud kepada Aisyah dan memintanya bersabar, juga pada Malik yang menurut panggilan orang tuanya :

Kiai Mahfud merangkul istrinya, "Aisyah, sabar. Kita harus sabar. Ini semua kehendak Allah.(Rosse, 2019:13)

" Iya, Abi!" Malik bergegas menghampiri ayahnya yang telah berjalan memunggunginya, masuk kembali ke rumah.(Rosse, 2019:18)

\begin{abstract}
Akhlak Buruk
Akhlak buruk adalah akhlak yang bertentangan dengan ketaatan terhadap Allah SWT, yaitu sombong, angkuh, kikir, malas beribadah, tidak sopan, ingkar janji, sering berbuat jahil, mencuri, berzina, berbohong, keras kepala, berkata kotor, durhaka pada orangtua, tidak membayar zakat, tidak menutup aurat, menggunjing, dan boros.

Kutipan Pada Novel "Dendam" si Yatim-Piatu mendeskripsikan nilai religius berupa akhlak buruk yaitu niyaha. Niyaha adalah menangis dengan suara keras dalam rangka meratapi kepergian mayit. seperti yang dilakukan malik ketika mengetahui Ibundanya telah meninggal dunia, terdapat pada kutipan berikut:
\end{abstract}


Malik meronta-ronta. “ Malik mau ketemu, Umi!” teraiknya.(Rosse, 2019:66)

\section{Nilai Budaya}

Penafsiran Temuan Penelitian tentang wujud nilai budaya berupa ide-ide, gagasan, nilai-nilai, norma-norma, peraturan dan lain sebagainya.

Menurut Tylor (dalam Tilaar, 2002: 37) mengenai budaya sebagai berikut : Budaya atau peradaban adalah suatu keseluruhan yang kompleks dari pengetahuan, kepercayaan, seni, moral, hukum, adat istiadat, serta kemampuan-kemampuan dan kebiasaan lainnya yang diperoleh manusia sebagai anggota masyarakat.

Dalam novel "Dendam" si Yatim-Piatu, terdapat kutipan mengenai sistem bahasa yang digunakan oleh orang yang usianya lebih tua kepada yang usianya lebih muda, dan sebaliknya orang yang usianya lebih muda kepada orang yang usianya lebih tua, yaitu sebagai berikut :

Masya Allah, Ujang. Ada apa? Kenapa hujan-hujanan begitu?(Rosse, 2019:2)

Di sampingnya duduk seorang paraji, Mak Juju(Rosse, 2019:3)

Terdapat pula, sapaan yang digunakan untuk anggota keluarga yang lebih tua, seperti kata Wak yang berarti kakak dari orang tua

Malik pamit, Wak, " Malik mengulurkan tangan, mencium tangan Wak Agus dan Wak Dedeh.(Rosse, 2019:41)

Terdapat norma yang baik dalam kehidupan bermasyarakat, berbakti kepada orang tua seperti menurut kepada orang tua atau suami, juga norma sikap rajin dan sabar.

Lagi-lagi Malik hanya mengangguk ketika ia dititipkan. Tak ada pertanyaan, kenapa? Mengapa? Ada apa? Ia manut saja.(Rosse, 2019:43)

Sifatnya yang rajin dan ringan tangan, tak heran membuat seluruh anggota keluarga Wak Koja, termasuk istrinya sangat menyayangi Malik seperti menyayangi anaknya sendiri.(Rosse, 2019:44)

Malik tidak pernah mengeluh. Ia makan dengan lahap. Seringkali mau nambah, tapi keinginan itu harus ditahan karena makanan harus cukup untuk anak yang kainnya.(Rosse, 2019:52)

“Kang, ke mana pun Akang bawa Nur'aini, ikut saja. Akang kepala rumah tangga.(Rosse, 2019:183)

Nilai budaya berupa sikap kejujuran, pemikiran, dan etos kerja yang baik seperti pada kutipan berikut : 
Keyakinan bahwa setelah 40 hari wafat sesorang, berkurang kesedihan yang ada dalam hati kelurga yang ditinggalkan, seperti yang dilakukan Wak Jumadi yang hendak mencerita semua yang terjadi kepada Malik setelah 40 hari kematian Ibunya.

Tepat 40 hari setelah kematian ibunya, Wak Jumadi merencanakan akan menceritakan segalanya kepada Malik.(Rosse, 2019:68)

Nilai budaya berupa pemikiran dan moral, yang diterima Malik atas keinginannya membalas dendam, namun dinasehati dan dilarang oleh Wak Jumadi.

Dendam dalam batinmu, apalagi sampai harus membalaskan dendam itu,

juga tidak akan mengembalikan semuanya. (Rosse, 2019:76)

Nilai budaya berupa norma pada keinginan dan cita-cita Malik untuk tidak mengecewakan orang-orang yang berjasa dalam hidupnya sebagai seorang yatimpiatu.

Ia berjanji akan belajar dengan giat dan tidak mau mengecewakan dua orang tua yang sudah berjasa dalam hidupnya. (Rosse, 2019:96)

Penafsiran Nilai budaya berupa ide dan pemikiran yang menjadi penyemangat diri malik dalam mengarungi kehidupannya.

Kau ingat pepatah, kan. Rajin pangkal pandai, hemat pangkal kaya.(Rosse, 2019:108)

Nur'aini tersenyum.” Banyak jalan menuju Roma, Kang, yang penting terpenting adalah kemauan dan niat baik yang tidak pernah putus."(Rosse, 2019:138)

Kesenangan tak selamanya bersembunyi, dan kesusahan tak seterusnya menghantui.(Rosse, 2019:210)

\section{Penafsiran Nilai Budaya sebagai kompleks aktivitas serta tindakan berpola dari manusia dalam masyarakat}

Kroeber dan Kluckhohn merumuskan definisi kultur dengan pola- pola tingkah laku dan pola-pola untuk bertingkah laku, baik yang eksplisit maupun yang implisit yang diperoleh dan diperoleh melalui simbolsimbol yang membentuk pencapaian yang khas dari kelompok- kelompok manusia, termasuk perwujudannya dalam benda- benda materi.(Geertz,1992:11)

Wujud nilai budaya berupa tindakan atau tingkah laku di masyarakat, tercermit pada kebiasaan membedong bayi. Bedong bayi adalah teknik membalut tubuh bayi, terutama bayi baru lahir, dengan menggunakan selimut atau kain bedong (lampin), agar bayi merasa nyaman dan hangat.

Mak Juju mengangsurkan sang jabang bayi yang sudah terbedong rapi itu

ke arah Kiai Mahfud.(Rosse, 2019:5)

Wujud nilai budaya pada ola tindakan, menggaruk kepala karena gatal melainkan karena kebingungan. Terjadi pada Malik ketika Ia merasa kebingungan, dan mencoba memahami apa yang dibicarakan oleh lawan biacarnya. 
Malik menggaruk-garuk kepalanya yang tidak gatal. Mencerna ucapan Hasan yang nyaris tanpa jeda.(Rosse, 2019:22)

Wujud nilai religius pada pola tindakan masyarakat pedesaan yang masih terdapat rawa-rawa, yaitu menjala ikan untuk butuhan hidupnya. Menjala ikan adalah pekerjaan mengangkap ikan menggunakan alat yang terbuat dari benang. Umumnya dilakukan oleh masyarakat pedesaan yang masih terdapat sungai, rawarawa atau danau.

Di kampung yang masih mempunyai lahan berawa-rawa itu, masa kecil Malik penuh warna. Selain kereta yang jadi penghibur hari-harinya bersama Hasan, Malik juga senang menjala ikan di rawa.(Rosse, 2019:29)

Wujud nilai budaya berupa pola tingkah laku adalah duduk bersilang kaki. Bersilang kaki adalah posisi duduk yang dianggap sebagai perilaku yang baik dan sopan, terutama pada masyarakat desa yang umumnya tidak menggunakan kursi, melainkan menggunakan balai yang terbuat dari kayu

Di atas balai di depan bilik, Wak Jumadi dan Malik bersilang kaki. Sesekali

Wak Jumadi mengusap-usap kepala Malik, menerawang sesaat bercerita.(Rosse, 2019:63)

Wujud nilai budaya berpa pola tingkah laku, mengangkat kedua jempol menunjukkan isyarat sikap senang terhadap suatu pekerjaan yang telah selesai dikerjakan dengan baik dan benar.

Wak Jumadi mengangkat kedua jempolnya sambil tersenyum

lebar.(Rosse, 2019:81)

\section{Penafsiran Nilai Budaya sebagai benda-benda hasil karya manusia.}

Menurut Selo Soemardjan dan Soeleman Soemardi merumuskan kebudayaan sebagai semua hasil karya, rasa dan cipta masyarakat. Karya masyarakat menghasilkan teknologi dan kebudayaan kebendaan atau kebudayaan jasmaniah yang diperlukan oleh manusia untuk menguasai alam sekitarnya agar kekuatan serta hasilnya dapat diabadikan untuk keperluan masyarakat. (Ranjabar,2006:21)

Lampu teplok mensyahdukan suasana di rumah-rumah penduduk.(Rosse, 2019:1)

Lampu teplok adalah lampu yang sumber cahayanya berasal dari sumbu yang dibakar menggunakan minyak. Umumnya dipakai masyarakat di pulau Jawa. Lampu teplok digunakan ketika Listrik belum merata, saat ini sudah jarang digunakan bahkan oleh masyarakat pedesaan karena, umunya masyarakat sudah menggunakan lampu listrik dan minyak tanah sebagai bahan bakar lampu sulit didapatkan setelah konversi BBM ke Gas.

Kiai Mahfud menutup tirai, berjalan mendekati pembatas kamar yang terbuat dari kayu.(Rosse, 2019:4) 


\section{Diskursus: Jurnal Pendidikan Bahasa Indonesia}

Vol. 3, No. 3, Desember 2020, pp. 226-239

p-ISSN: 2615-4935

e-ISSN: 2615-4943

Rumah pada jaman dulu biasa menggunakan kayu sebagai dinding kamar, terkadang menggunakan ayaman dari bambu, yang pada saat ini dianggap sebagai rumah semi permanen.

Tersayat pisau sunat dan terbawa pada kulit yang terpotong.(Rosse, 2019:10)

Pisau sunat adalah alat tradisional berupa pisau yang digunakan untuk memotong kulup pada penis anak-anak, tanpa menggunakan obat bius. Namun saat ini sudah jarang digunakan, karena sudah banyak dokter serta majunya ilmu kedokteran ada yang mengkhitan menggunakan laser.

Pak Dadang segera meramu obat-obatan tradisional untuk dibalur di atas luka agar cepat mengering.(Rosse, 2019:11)

Obat-obatan tradisional adalah bahan atau ramuan berupa tumbuhan, bagian hewan, mineral, atau campuran dari bahan-bahan tersebut yang digunakan secara turun-temurun untuk pengobatan. Obat tradisional juga sering disebut Obat Bahan Alam. Kita dikenal dengan sebutan obat-obatan herbal.

Ia tidak mau ikan-ikan itu cepat mati jika diletakkan di korang.(Rosse, 2019:32)

Korang adalah tempat menyimpan ikan hasil menjala atau memancing, berbentuk seperti kendi, terbuat dari anyaman bambu.

Di sisi kiri dan kanan jalan berdiri rumah-rumah penduduk yang sebagian besar masih berbentuk bilik, lantainya terbuat dari papan, atapnya terbuat dari daun rumbay.(Rosse, 2019:42)

Rumah berbentuk bilik adalah rumah tradisonal berbentuk panggung yang lantainya terbuat dari papan, adan atapnya terbuat dari daun rumbay.

Membawa cangkul yang terletak di balik pintu belakang.(Rosse, 2019:79)

Cangkul adalah alat tradisional pertanian yang digunakan untuk menggali dan mengaduk tanah, dibuat dari lempeng besi dan diberi tangkai panjang untuk pegangan.

Malik juga tidak segan belajar membuat Oyek.(Rosse, 2019:80)

Oyek adalah bahan dasar nasi yang terbuat dari ketela pohon/ubi kayu/singkong. Bentuk oyek adalah butiran bulat sebesar kacang ijo yang berwarna coklat kekuning-kuningan. Cara membuat Oyek: Singkong dikupas/dibersihkan lalu dipotong-potong kemudian direndam memakai air bersih selama 3 hari. 
Jika padi sudah dihamparkan di atas giribig.(Rosse, 2019:86) sunda.

Giribig adalah sebutan alas yang terbuat dari anyaman bambu bagi orang

\section{SIMPULAN}

Berdasarkan hasil penelitian uamh telah dilakukan pada novel "Dendam" si Yatim-Piatu karya Sintha Rosse, dapat diambil simpulan bahwa temuan Nilai Religius yang terdapat dalam penelitian berupa Akidah terdiri dari Iman kepada Allah, Iman kepada Malaikat, Iman kepada Rasul dan Iman kepada qadla dan qadar sebanyak 35 atau 27,34\%. Nilai religius berupa Akhlak terdiri dari akhlak baik dan akhlak buruk sebanyak 46 atau 35,93\% dan Nilai Religius berupa Syariah terdiri dari ibadah sholat, menuntu ilmu, menikah dan pergi haji yang sebanyak 47 atau $36,71 \%$ dan temuan nilai budaya yang terdapat dalam penelitian ini berupa ide, gagasan, nilai, norma, peraturan dan sebagainya terbesar yaitu sebanyak 42 atau $38,53 \%$. Sementara wujud budaya berupa aktivitas serta tindakan berpola dari manusia dalam masyarakat sebanyak 30 atau 27,52\%. Temuan benda-benda hasil karya manusia sebanyak 37 atau 33,94\%.

Saran diberikan bagi pembaca yang berasal dari segala usia, latar belakang yang berbeda dan agama terutama Islam yang senang membaca, Novel "Dendam" si Yatim-Piatu ini bisa menjadi salah satu novel untuk direkomendasikan bagi para pencinta novel. Isinya yang diangkat dari kisah nyata akan memberikan nuansa tersendiri bagi para pembaca. Nilai-nilai religius yang terdapat pada novel ini sangat baik untuk perkembangan rohani pembacanya, dan nilai-nilai budaya yang ada didalamnya sangat penting ditanamkan pada pembaca usia muda di tengahtengan gencarnya budaya asing yang destrktif terhadap pembentukan nilai-nilai religius dan nilai budaya leluhur yang menjadi identitas bangsa Indonesia.

\section{DAFTAR PUSTAKA}

Ahmadi, R. (2016). Metodologi penelitian kualitatif. Yogyakarta: Ar-Ruzz Media. Geertz, C. (1992). Tafsir kebudayaan, Terj. Fransisco Budi Hardiman. Yogyakarta: Kanisius.

Hilaliyah, H., \& Awaludin, A. (2016). Implikatur percakapan pada novel Teheran Dalam Toples karya Aminatul Faizah. DEIKSIS, 8(01), 71-85.

Marzuki. (2012). Pembinaan karakter mahasiswa melalui pendidikan agama islam di perguruan tinggi umum. Yogyakarta: Ombak.

Moleong, J. L. (2002). Metodologi penelitian kualitatif. Bandung: Remaja Rosda Karya.

Pradopo, R.D. (2008). Beberapa teori sastra, metode kritik, dan penerapannya. Yogyakarta: Pustaka Pelajar.

Ranjabar, J. (2006). Sistem sosial budaya indonesia: Suatu pengantar. Bogor: PT Ghalia Indonesia.

Rosse, S. (2019). “Dendam” si Yatim-Piatu. Tangerang : Pustaka Mandiri. 
Diskursus: Jurnal Pendidikan Bahasa Indonesia

Vol. 3, No. 3, Desember 2020, pp. 226-239

p-ISSN: 2615-4935

e-ISSN: 2615-4943

Sugiyono. 2010. Metode penelitian pendidikan pendekatan kuantitatif, kualitatif, dan $R \& D$. Bandung: Alfabeta

Sugiyono. (2012). Metode penelitian kuantitatif kualitatif dan $R \& D$. Bandung: Alfabeta.

Sangidu. (2004). Metode penelitian sastra, pendekatan teori, metode dan kiat. Yogyakarta: UGM.

Sudaryanto. (2015). Metode dan aneka teknik analisis bahasa. Yogyakarta: Duta Wacana University

Sahlan, A. (2010). Mewujudkan budaya religius di sekolah (Upaya mengembangkan PAI dari teori ke aksi). Malang: UIN Sunan Kalijaga.

Tilaar, H. A. R. (2002). Membenahi pendidikan nasional. Jakarta: PT. Rineka Cipta. 